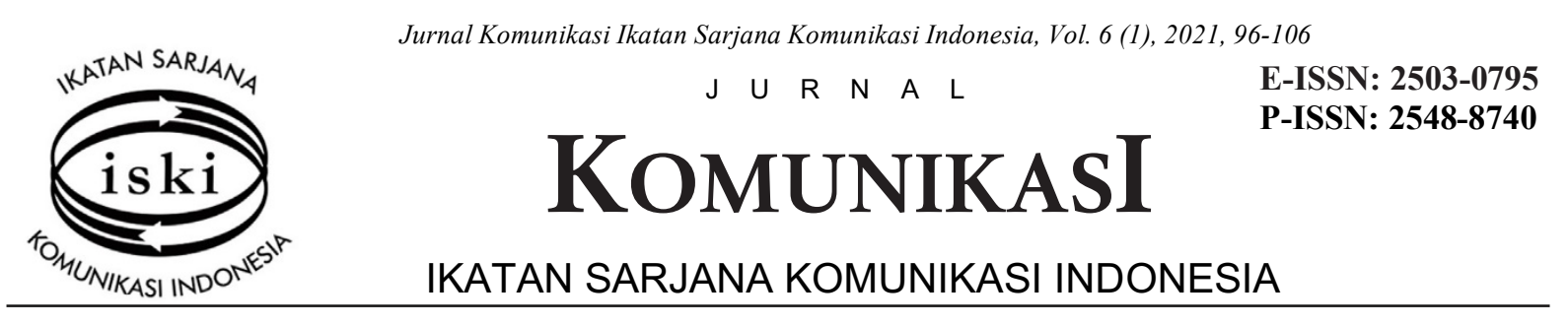

\title{
E-Church as a Virtual Service Communities During COVID-19 Pandemics
}

\author{
http://dx.doi.org/10.25008/jkiski.v6i1.509
}

\author{
Kartika Singarimbun \\ London School of Public Relations Communication and Business Institute \\ J1. KH. Mas Mansyur Kav.35, Jakarta 10220 - Indonesia \\ "Corresponding author: kartika.s@1spr.edu
}

Submitted: February 24, 2021, Revised: March 30, 2021, Accepted: May 19, 2021

Accredited by Kemristekdikti No. 28/E/KPT/2019

\begin{abstract}
COVID-19 threatens the survival of many people. The imposition of social isolation, social distancing, and lockdown policies, shuts down face-to-face worship at the church. Despite the stuttering information technology, the Protestant churches gradually broadcast the worship Livestream Youtube and save the video afterward; so that the congregation can watch the e-church further. The adoption of communication technology has become a new strategy for church institutions during the pandemic; by creating channels for congregations. With the theory of mediatization of religion, media used to delivering religious content, and as Protestant virtual communities, environment to gather and participate in real-time Sunday worship on youtube Livestream. E-church is the main target of Indonesian church institutions today, although it cannot be denied that many communication aspects are missing; such as touch, emotion, and expression. By using the Indonesian Christian Church known as GKI Taman Cibunut Bandung as a case study, multi-sources of informants who were interviewed semistructured were conducted so that the data were obtained comprehensively.
\end{abstract}

Keywords: Computer-mediated communication; COVID-19; e-church; virtual service; Sunday services

\section{Introduction}

Since President Joko Widodo (Jokowi) declared COVID-19 pandemic a national disaster in Indonesia (in March 2020) and Bandung City imposed a lockdown policy in April 2020, local residents have not freely ventured outside their homes. At the time this paper was written, the number of COVID-19 patients in Indonesia had reached 1.1 million, and the number of COVID-19-related deaths had touched 31,000. Offices, schools, campuses, malls, recreation areas, places of worship are closed. Employees do their work from home, known as WFH, students and university students also study from home, known as SFH. Not all activities are permitted. The imposition of the lockdown policy led to the government banning crowds. As a result, churches suspended indoor worship. The Indonesian Christian Church, locally known as Gereja Kristen Indonesia or GKI, has many branches in the country. One of them is GKI Taman Cibunut located in Bandung City. Founded in 1926, GKI Taman Cibunut is the oldest Protestant church in Bandung and now has a congregation of 2,777 people (GKITC Annual Report, 2020). What is the impact of COVID-19 pandemic on Protestant churchgoers and how do they worship?

World Health Organization (WHO) has declared COVID-19 as a pandemic that threatens human survival (World Health Organization, 2020) on March 11,2020. The COVID-19 disaster has dire consequences in 
the world. The impact of the pandemic on human survival in the world is undeniable and unprecedented. Of the many possibilities in overcoming feelings of insecurity, religion plays an important role. As a religious organization, most of the churches in the world break off their worship, thereby sparking a debate among Protestant church leaders in Indonesia. Some Protestant leaders consider that the church is a place of transmission of the virus that spreads rapidly because of the number and distance of congregations while sitting in the building and the duration time of services. Therefore, churches were among the first institutions to shut down services to thwart the rapid spread of the virus.

Research on virtual worship is quite common in developed countries; while the UK locks down, online worship becomes an option (Village \& Francis, 2020) Research on the spread of the COVID-19 and its relationship to religion for congregations in several countries also adds to the collection of writings on religion and COVID-19 (Wildman, Bulbulia, Sosis, \& Schjoedt, 2020). Chu, (2021) conducted research on the Hong Kong's people theological reflection in the pandemic, (Molteni et al., 2021) conducted research in Italy for families who have infected with COVID-19 and their relationship with seeking worship services. Religious revival has increased since the pandemic hit the world (Bentzen, 2020), Google searches for topics related to prayer, and research proposes to pray for people in the US; their faith has become stronger because of the pandemic.

There is quite a lot of researches on COVID-19 in Indonesia, but the number of articles focusing on e-church or virtual worship is limited. Some papers discuss COVID-19 and worship in terms of the importance of building spirituality in the family (Arifianto, 2020) and responses to COVID-19 in Indonesia (Andayani, 2020; Djalante et al., 2020; Regus, 2021; Sukamto \& Panca Parulian, 2021). The paper that discusses worship during the pandemic; focuses more on the theological side (Surna \& Suseno, 2020; Yuono, 2020).

GKI Taman Cibunut Bandung is one of the churches that have grown rapidly since 1916 . It is the oldest Protestant church in Bandung, which has an iconic heritage building. GKI Taman Cibunut Bandung uses the Indonesian language for its services because the congregation is made up of various ethnic groups in Indonesia that have their own language. Since the mayor of Bandung imposed a lockdown policy geographically, followed by social distancing rules, GKI Taman Cibunut Bandung responded to the recommendation by breaking off the Sunday services. However, after one church pastor in Bandung died of COVID-19, the second death related to the infection in Indonesia, many churches decided to close their services.

As a limited research on the use of media for Sunday worship in Bandung, this article helps reduce the research gap by examining the communication media used by Protestant church institutions in this study, GKI Taman Cibunut Bandung. This article aims to analyze the use of communication channels by church institutions through computer-mediated communication concepts that manage ideas/messages and information through communication technology; online media. The media serve as an agent of change in the delivery of worship which is at the core of the theory of the mediatization of religion. Religious institutions; GKI Taman Cibunut Bandung, as an object of this research is increasingly dependent on the media as an institution. The media become a channel for religious institutions to convey their messages to socially isolated people.

\section{Theoretical Framework}

Due to the COVId-19 pandemic, humans become socially isolated; wearing masks and keeping a distance of at least 1 meter from other people during lockdown geographically. "Work and school from home" is imperative for humans not to be exposed to COVID-19. The church responded quickly when President Jokowi ordered local governments to provide territorial isolation. This caused churches to immediately convert face-to-face worship to virtual worship. (Hjarvard, 2008), a media sociologist from Denmark, offers a theory of religious mediation. The mediating assumption is a two-way process by which media institutions must be accommodated; in this case; religion. Through the process of mediation, religion enters the logic of the media; as a channel for delivering content, an environment where communication-mediated communities gather. The media has become a channel of communication in the Indonesian church community during this COVID-19 pandemic; used as the main source of religious ideas. Text, symbols, and imagery by virtual worship/e-church are combined by the producers when building stories or films. The 
media forms a religious "movie" for the audience through e-church shows every week.

Religious mediation is a modern phenomenon that has been used by western societies, where church presence is very limited. In contrast to Indonesian society as a developing country, religious mediation is a new thing as Christians attended Sunday services inside the church building before the COVID-19 pandemic. The media as a channel; explains how this communication is mediated. The media carries messages and symbols across the distance from sender to recipient. Media content; messages, is conveyed, topics and audience attention is important. YouTube LiveStream of worship or e-church present religious representations in new ways. The media are distributors of the e-church collection when the Livestream takes place and afterward. Media as an environment technically provide services in line with global communication. The media take over the authority of church institution as a provider of information for groups of people.

Computer-mediated communication (CMC) is the incorporation of all forms of communication between congregations and church institutions via computer networks that began to be researched in the 1990s (Campbell, 2012). CMC plays an important role in sharing, discussing, and negotiating knowledge over networks and opened new horizons for production, delivery, storage, download, and access to information. The term virtual community was introduced by Helland in 2000 (Campbell \& Delashmutt, 2014), where the church uses communication technology for its religious activities pioneered by The Catholic Institution as a form of church communication (Campbell \& Vitullo, 2016). A theoretical approach to categorizing religion online or in terms of virtual communities was also carried out in the same year. In 2001, an international religious and computer-mediated communication conference took place in Copenhagen. The questions raised in the confirmation regarding the internet with religion and the experience of Christian congregations being mediated online were discussed in more depth. After that conference, a growing number of researchers have tried to outline a theoretical-methodological approach (Hutchings, 2011). The use of the internet increases the capacity for church ministry and encourages new forms of spiritual relationship, engagement, and the most notable innovation is the change from Sunday service inside the church to virtual worship (Newport, 2020), and is a continuation of worship that has stalled due to the pandemic; using the YouTube platform, including churches in Indonesia.

\section{Material and Methodology}

This research uses a qualitative approach with the case study method, because of the time of the event and case being studied (Yin, 2014). A qualitative approach is used because the aim is to explore and understand what is hidden behind e-church services that use digital videobased online Livestream media. In-depth observation of human behavior and the environment is necessary to reveal social realities. Case studies as a research method aim to explore phenomena within a certain period of time which are still ongoing in the form of activities, programs, institutions, socialcongregation groups, and gathering information using various data collection procedures during the period of March 2020 to January 2021. The type of case study used is a single case study; a case has a specificity that is unique in contrast to other cases.

The data collection method uses semistructured interviews which allow a series of questions to be asked and developed further from the informants' answers. All questions were prepared openly so that participants could give their words of answers and expand on them, if needed. The interviewer has a relationship with the participants as members of the church at GKI Taman Cibunut Bandung. This way, the interviewer gets to know the participants before the interview takes place and this is very helpful in creating a more relaxed atmosphere for data collection. However, it should be emphasized that the objective attitude of the interviewer was continuously built in the data collection process.

During this pandemic, interviews were conducted in two ways, face-to-face interview and zoom call. Interviews were conducted at the GKI Taman Cibunut Bandung's building in compliance with the health protocols; wearing a mask, keeping a distance of 1 meter while raising questions and recording answers. Likewise, telephone interviews were recorded using applications on mobile phones. The study involved nine research participants based on their central position as decision and policymakers (Knuth, Kouki, \& Strube, 2013), four of the participants were the board of elders, one priest, music commission, a multimedia commission from the GKI Taman Cibunut's member. Local government informants were 
important to get involved in this study because of their duties to supervise the health protocols in the area. This research was conducted from September 2020 to February 2021.

The interview resulted in a discussion that helped the interviewer get more detailed information about the process of forming a multimedia team for the Youtube Live Stream worship, the rehearsal process for worshipers, the use of e-church services for the congregation, how to get local government permission to make video live streams inside the church building, adherence to health protocols by people who are present in the church building. Data collection allows the creation of an atmosphere of communication when the interviewer attended the online worship rehearsal, when the YouTube Live Stream worship took place in the church and when the interviewer watched the e-church athome.

\section{Result and Discussion}

GKI Taman Cibunut, located in Bandung, West Java, Indonesia, represents the spectrum of how churches in Indonesia have responded to the COVID-19 pandemic. The e-church GKI Taman Cibunut started on March 22, 2020. The online worship was previously held twice on Sundays, at 7 and 9.30 in the morning. However, the e-church is later held only every Sunday and the congregation can watch the service via YouTube GKIT Taman Cibunut at other times. GKI Taman Cibunut uses the term "live stream on youtube" for the real-time Sunday services as stated on the e-church news bulletin. GKI Taman Cibunut is one of the churches that has responded very quickly to the government's lockdown policy, while several other churches still held indoor services until April 2020.

\section{The Synodal Presbyterian Church}

GKI Taman Cibunut was built in Bandung by the Dutch colonial ruler in 1916. Dutch priests took turns pastoring the congregation, which reached 900 people. This congregation, together with other congregations in the Dutch East Indies, united in the Batavian Classical and tied themselves up in the Generale Synode van de Gereformeerde in the Nederlands until a certain period of time when the political situation in Indonesia was not possible. At that time, the Dutch returned to their country, so that the number of members decreased to only 34 .

Since then, Indonesians began to attend the services. The First Indonesian priest was attestation in 1958. Then GKI Taman Cibunut released its synodal ties with the churches in the Netherlands and united itself in the synodal of the Indonesian Christian Churches in Central Java in the same year. In this regard, a GKI institution in West Java was present. It has synod ties with the synodal GKI of Central Java. Furthermore, GKI Taman Cibunut has taken part in classical, synodal, and ecumenical activities. GKI Taman Cibunut co-founded the 'Bumi Baru' Funeral \& Cremation Service Foundation, Yahya Christian Education Foundation (1962), which developed Christian education/school activities, Dana Mulia Christian Orphanage Foundation (1971), which takes care of orphans, Yayasan Dana Sejahtera (1976), which supports the bereaved families of the members, and the 'Hidup Baru' Christian Education Foundation (1981). GKI Taman Cibunut also developed Congregation and built three churches. They are GKI Pasteur (1987), GKI Arcamanik (1989), and GKI Rancaekek which are in the process of growing into churches (GKISW Jateng, 2020).

GKI Taman Cibunut has a long and continues to grow. The Board of elders or parish council of GKI Taman Cibunut consists of ecclesiastical officials or parties, namely "Priests" and "Elders". Elders are members of the congregation chosen by the congregation as their representatives. The Board of elders runs the church institution. In the synodal Presbyterial system, all decisions are made based on a collective agreement instead of the existing authority of either party. Therefore, the meeting is an integral part of the development and service policy-making process in the scope of the Congregation, Regional Synod. Ecclesiastical assembly is not limited to institutional management only but also has a spiritual meaning; seeking and doing God's will for His church. The board of elders carries out the functions and responsibilities of leadership collectively (priests and elders). There is no hierarchy that places one party higher than the other. Elders and priests essentially have the same position in the sense that one is not below or above the other. Thus, in the GKI, there is no hierarchy of ecclesiastical positions.

\section{GKI Taman Cibunut Congregation}

GKI Taman Cibunut is known as a church whose congregation is mostly made up of people of Chinese descent. However, in its later development, the congregation comprises various ethnic groups. Indonesia is an archipelago of more than 17,000 islands which 
has 1,340 ethnic groups (BPS, 2010). They speak their respective languages. However, in each of its services GKI Taman Cibunut uses Bahasa. The services are carried out three different times every Sunday, 7 am, 9.30 am, and $5 \mathrm{pm}$.

GKI Taman Cibunut congregation is quite diverse in terms of ethnic group. According to one priest, they are well educated and critical. Ideas flow smoothly in commission meetings but lack of people are committed to making them happen. The priest further explained the character of the members that they were reluctant or shy to express their feeling of others, it was uncomfortable to reprimand for respecting that person. As (Hooker, 2012) mentions the concept of Asian culture; highcontext communication which tends to speak not straight to the point; polite statements before explaining the real intention. Their appearance is also modest while attending services, which will be different if attending Sunday services of a tribal church, for example, the Batak church. According to one of the elders, the members are friendly and reprimands each other. With 2,777 active members, it is possible for members not to be acquainted with others. There are also many members who only attend Sunday services, but not attend the district fellowship held every month.

The Catholic churches have used ecclesial communication for long enough. In 1957 Miranda Prorsus Pius XII encouraged the use of new technology to empower congregations. Virtual communities are the new nuances of religion introduced by Helland in the 2000s. The phenomenon of the virtual world and virtual religious communities has been running in America and Europe and has been researched to see how these virtual religious communities share their religious experiences and adapt to virtual cultures. Investigations have been conducted into how virtual communities construct their interactions and patterns in cyberspace.

How about the virtual communities in Indonesia? Most Indonesian Christian communities visit Sunday services regularly. Apart from worship, the church is a place for interaction between congregations as a Christian family. The GKI Taman Cibunut members are quite active in the activities such as the fellowship, groups of Indonesian traditional music players (angklung and kulintang), and orchestras that regularly participate in the liturgy services. The activity that the church provides is not only a place for interaction between congregations but also as an effort to grow. With these various activities, members of the congregation can choose activities that are suitable to them. The church is also a place for people to give their donations to others who are in need.

When President Jokowi stated that two Indonesian citizens were confirmed positive for COVID-19 on March 2, 2020, that was the beginning of the pandemic in Indonesia ( https://www.kompas.com/tren/read/2020/07/28 /060100865/perjalanan-pandemi-covid-19-diindonesia-lebih-dari-100.000-kasus-dalam-

5?page=all). One month after the announcement, 34 provinces in Indonesia confirmed the COVID-19 patients, and then the President issued Decree No. 12 of 2020 declaring the Coronavirus Disease (COVID-19) outbreak in Indonesia a non-natural national disaster. Meanwhile, three people with confirmed COVID-19 passed away and 26 people tested positive for the infection in Bandung on March 20, 2020 (https://tekno.tempo.co/read/1321940/covid19-pasien-pertama-meninggal-di-bandungpunya-penyakit-lain/full\&view=ok). For its part, the Governor of West Java imposed LargeScale Social Restrictions, known as lockdown, in the areas of Bandung City, Cimahi City, Bandung Regency, West Bandung Regency, and Sumedang Regency, West Java on April 22, 2020. This lockdown policy was socialized to the public based on Gubernatorial Decision Number 443/Kep-240-Hukham/2020 concerning the enforcement of lockdown in the Bandung area and environs in the context of accelerating the handling of the COVID-19 which is valid until 5 May 2020 (https://www.cnnindonesia.com/nasional/2020 0422071248-20-495899/tangkal-corona-psbbbandung-raya-mulai-berlaku-hari-ini).

The implementation of lockdown is quite challenging for Indonesian people who embrace a collective culture. Not seeing friends and relatives, social distancing, and wearing masks is quite difficult. Indonesian people like to gather, especially Sundanese; Bandung residents who adhere to the high-context communication system. When a smile is not visible because half of the face is covered with a mask, people cannot touch while speaking, and even shaking hands are avoided. This kind of behavior to self isolate is uncomfortable for some people and causes stress. The implementation of lockdown and stay-at-home policy without meeting other people is quite difficult. Lockdown or social isolation ends 
relationships without a wider circle of friends (Gierveld, van Tilburg, \& Dykstra, 2009). Social distancing is carried out to prevent the spread of the virus by reducing contacts between humans who may have been infected (Centers for Disease Control and Prevention [CDC], 2019). Even if we meet face to face, keeping a distance of at least 1 meter and wearing a mask can protect us from droplets of breathing, in addition to washing their hands frequently. Everyone who participates in reducing limited contact is believed to be able to reduce the spread of the virus (Del Valle, Hethcote, Hyman, \& Castillo-Chavez, 2005).

The Invocation social distancing from governments has an impact on Sunday service at churches. Interaction in Christian environments uses touch which is transmitted emotions between individuals (Goldstein, Weissman-Fogel, \& Shamay-Tsoory, 2017). There are a lot of tactile interactions during their activities, such as being greeted shake hand or hub by the board of elders when the congregation enters and leaves the church building. During services, the priest asks the congregation to stand and shake hands with others. Interaction between congregations in the form of talking, touching, and shaking hands has become a habit; has made the church leaders follow the instruction of social distancing which has been implemented by several churches nationwide.

Church activities in Bandung have stopped since March 22, 2020, simultaneously, including other activities in the building. The fear of COVID-19 transmission led to virtual worship as an option. The e-church service is the only way for the church to reach its members. Even though it requires a home wi-fi or internet to view the e-church services which are quite expensive for some people, the network connection is sometimes unstable. Technological isolation took place; although Bandung is a progressive city, the internet connection is not evenly distributed. As a consequence, the technological isolation has an impact on social isolation which cuts off conversations with friends and family and has an impact on depression and fatigue.

People who self isolate need to rebuild their hope through meaningful relationships; to re-establish control over their situation which leads to increased personal power. For Bandung residents who self isolate due to the COVID-19 pandemic, computer-mediated communication (CMC) can help relieve feelings of isolation through WhatsApp video calls, zoom, google meet; thereby that kind of communication empowering isolated people to build social relationships (Ngwenya \& Mills, 2014). Whatsapp videocall, zoom, and google meet are some applications in the new media that usually are used to substitute face-to-face communication. Even though each party cannot touch, images from the video display can alleviate feelings of social isolation and are a form of recognition. Then, what about spiritual isolation; in which the congregation cannot present the Sunday services in the church building? Computer-mediated communication or CMC is the best answer for the recent situations. GKI Taman Cibunut as a religious institutional conducts research for the needs of the congregation during the pandemic.

In fact, the Indonesian Christian Church, known as Gereja Kristen Indonesia or GKI as a whole, was stuttering and unprepared for the virtual service. On the zoom meeting conducted for all Indonesian Christian Church, Priest Adi Patriabara explained that virtual communities are inevitable which are united by the same symbol and meaning, but at the same time, it is different from other communities. Churchfriends-family can become a symbol and meaning that is strengthened even more. The essence of the church is a friend that embraces all people (Acts 2:47) and in the results of hospitality is strangers as friends or being friends to strangers. The church is close to Sunday service as hospitality; as the continuation of human survival and the church does not rush to open services. The friendly church lives in the midst of a pandemic prohibit physical meeting so that the choice is virtual.

Every church has its own culture. The organizational culture of the Indonesian Christian Church, known as Gereja Kristen Indonesia or GKI Taman Cibunut, has a background that was built by the Dutch (1916), initially had members of the Chinese ethnic group, and is now more pluralist in terms of ethnicity and social status. The GKI is a Calvinist Protestant, a synodal presbyterial that adheres to equality in membership. The organizational culture of the church determines the identity and boundaries between one church and another, produce a commitment to live together in the community including while this pandemic hit Indonesia. This commitment that is built-in togetherness has the decision to prohibit physical encounters and start online worship. Although GKI Taman Cibunut does not have a tool for live broadcasts for Sunday services, the multimedia commission 
aggressively finds a good broadcast quality. The multimedia commission chairman of GKI Taman Cibunut, VX, stated that in the early days of e-church, they borrowed a camera from another church that had served worship via the web.

Without enough knowledge and experience, the multimedia commission of GKI Taman Cibunut decided to broadcast LS through the Youtube channel. The first thing to do was creating a GKI Taman Cibunut YouTube account and fortunately, YouTube allows churches to open accounts without having 1,000 subscribers. Two options for echurch are "Livestream Sunday service" or "recording Sunday service". However, from the results of a research conducted on church members by the multimedia commission of GKI Taman Cibunut, they decided to Livestream the Sunday service. Apart from that, recording is quite difficult and requires more human resources in terms of editing and camera angles, so that Livestream is considered the same as Sunday service in a church building. The only difference is the presence of the congregation.

E-church as an Innovative Way During COVID-19

The use of advanced technology transmission makes the world a global village. Online worship is not different from gathering a spiritual entity and worshiping on the face-toface interaction. Although this argument is intended to preserve the life of the human in accordance with the Indonesian Christian Church-Central Java Synode's vision; to be God's partner in appreciating Indonesian peace, and realizing peace in the society as the GKI Taman Cibunut's vision by encouraging closeness fellowship in the unity of Christ. Various commissions of GKI Taman Cibunut were formed based on age groups; children aged under five to 7 years, commission for youth aged 13-16 years, commission for adults aged 17 years and above and commission for elderly aged 60 years and above. Each commission is accompanied by 1 elder and priest to make sure the commission is running.

This multimedia volunteer does not have the YouTube live broadcast experience yet but with their friend's experiences and borrowed tools such as studio switcher and camera, they were determined to try their first Youtube Livestream on March 22, 2020. Before the Livestream started, the chairman of the GKI Taman Cibunut board of elders made a piece of video information about online worship which was displayed on the YouTube account of GKI Taman Cibunut Bandung. Only the YouTube channel is the digital platform that can reach the congregation, according to the head of the GKI Taman Cibunut multimedia commission. YouTube is a popular channel in Indonesia, and many artists and celebrities have an account to create their content to connect with fans.

To produce an e-church, a program for all people aged 17 years and above requires talents to able to convey spiritual messages. For its part, rehearsal is conducted every Saturday to minimize errors. "Affairs1" of GKI Taman Cibunut board of elders who prepares the liturgy of worship, and the second is the "Music Commission" who prepares four kinds of the performer; pianist, psalmist, song leaders, and a group of praise. Lastly, for visuals LiveStream is the "Multimedia Commissions" responsibility. Music Commission and Multimedia Commissions have supported the Sunday service. Affairs1 of GKI Taman Cibunut who is a member of the board of elders stated that since YouTube LiveStream worship. They were quite busy coordinating with two supporting commissions (music and multimedia), such as organizing the time of rehearsal, the flow, and the assignments of each role so that the e-church worship is like the Sunday service.

During Saturdays' rehearsal, all parties have to follow government health protocol; washing hands before entering the church building, checking body temperature (not more than 37.5 degrees Celsius), wearing a mask or face shield while in the church area, and keeping a distance of at least 1 meter to other people. It was quite tiring for the participants because they talked repeatedly with others due to physical distancing and wearing a mask, while the air conditioner was turned off due to the circulation, thus making them uncomfortable. Before and after being used, the church building was sprayed with disinfectant which is believed to prevent the spread of the virus. In the first 2 months, the e-church worship was live-streamed. When the local government eased the restriction in the yellow zone, marked with a decline in the number of COVID-19 patients; the GKI Taman Cibunut's board of members resumed the Sunday service for public but with limited seats available.

There are 15 public health indicators consisting of 11 epidemiological indicators, 2 public health surveillance indicators, and 2 health services. The following are 15 health indicators used by the government to determine 
COVID-19 zoning. The number of positive COVID-19 cases, the number of deaths over the last 2 weeks, the number of recoveries, the decrease in mortality rate per 100,000 people, the number of referral hospital beds that can accommodate the patients (https //: covid19 .go.id, 2021) Each region will receive different scores from the 15 indicators above. The scores and weightings of an area will be added up. The results will be categorized into zones based on colors, as follows: (1) 1.Red zone: high risk zone (score 0 to 1.8 ); (2) Orange zone: moderate risk zone (score 1.9 to 2.4); (3) Yellow zone: low risk zone (score 2.5 to 3.0); (4) Green zone: no affected zone, no positive COVID-19 cases were recorded.

The local government allows churches to open for the public under several conditions. One of them is reporting to sub-districts based on regulation No. 37/2020. Before conducting Sunday services in the church (on-site), GKI Taman Cibunut prepares the area to be reviewed by sub-districts according to health protocols; the congregation was only allowed to attend the on-site worship at $30 \%$ of the room capacity (75 people) by registering with the church. GKI Taman Cibunut was split into 15 small areas and 5 large areas. Worship in the large areas was only allowed to have 17 people each. Worship at the church was divided into 2 services, at 07 and $10 \mathrm{am}$, while the Livestream was only held at $7 \mathrm{am}$. The service at the church took place from September to November 2020, and was broken off due to a spike in COVID19 cases in the Bandung area.

Yet, e-church or Livestream worship is still debatable whether it is kind of the ecclesia? In general, the understanding of the Christian ecclesia is conventional; through the physical encounters as it's written in the bible. Face-toface interaction, the fellowship of disciples of the Lord Jesus, they interacted, evolved into a church, as stated by one of the priests of GKI Taman Cibunut. The question is whether the virtual worship is not a face-to-face communication; no eye contact, cannot see gestures, mimics, and expressions of both parties, the priest and his congregation. The online worship or e-church was blocked by the media which acted as one-way communication. For the pastor who preaches, he can only presume the congregation's understanding of the message he conveys.

"Without a congregation's presence, it is difficult, because the direction of my conversation depends on the expression, it depends on the presence of people. If I talk about something, sometimes the congregation smiles, and that smile gives me a little direction to where is this discussion going ?" (Priest NVS, 2021).

Their expression who listens to the sermon becomes the direction for the priest's message to convey, which he prepares the script by the pointer. The reaction will cause the priest as a speaker to feel comfortable and have the option to explore the topic or shorten it, depending on the audience's expression and response. On the other hand, as an audience of the YouTube Livestream worship, congregants who watch at home do not feel emotional or closeness with priests' messages. Another drawback is that the congregation does not need to dress up nicely during the worship at home, and even some of them have not showered. The audience or congregation looked modest fashion. Initially, the audience watched YouTube Livestream worship at the same time. But later they watched the worship shifted to other time.

Apart from the audience's fashion appearance, the congregants who watched the echurch were also not seated nicely. Some of them stated that initially, they watched the Livestream worship together with other family members, but after a few weeks, each family member chose to wacth the Livestream worship according to their own time. Changes also occurred from those who previously took a shower and were dressed neatly before watching the Livestream worship but later made no preparations, like not taking a shower, not being dressed modestly, waking up then opening YouTube worship and following echurch shows while lying down on the bed.

In terms of Livestream worship viewers, their number ranges from 18 to 250 until the end of the show. It is not known whether the viewers on YouTube LiveStream worship are GKI Taman Cibunut members or not. But the audience continued to increase, between 1,200 and 2,300 in each e-church worship compared to the number of on-site Sunday services in the church for the 7 am service at around 290, for 09.30 am service at 560 , and for afternoon service at $5 \mathrm{pm}$ at 112 .. Of the 2,777 registered congregations, less than 1,100 attended the church, including children and youths whose worship room is separated from that of adults.

Sunday service has become a necessity before the pandemic, but the e-church worship appeared not to answer the spiritual needs of most of the GKI Taman Cibunut's 
congregations. Elderly, adult congregants who were interviewed stated that participating in the worship both on the Livestream and afterward was like watching a movie; clone of reality and it is not real. Many are hidden and are not shown in that "movie". Song Leader and pianist are only visible on the congregation's screen when guiding them in singing. Likewise, the presence of the priest can only be seen when the camera focuses on the preaching. It's different when the congregation is present in the church, where they can see all the worshipers and feel the atmosphere inside the church building.

Even though the YouTube Livestream worship shows inside the church, but the camera highlights follow the liturgical rundown. The "movie" shows have not been perfect in presenting the image of the congregation according to their mind while attending the services inside the church. Switching between two cameras is not as smooth as making movies because the cameraman volunteers have to develop their abilities. In addition, sometimes network technical problems happen during the Livestream and cause the worship image to stop. And for pianists, the absence of the congregation affects their performance. A pianist who has served for 10 years at GKI Taman Cibunut mentioned that her emotions do not build up. The purpose of playing the piano is to lead the congregation to sing, but with Livestream, she only played accompanies the 2 song leaders. The nuances, chemistry, emotions that she built through the music arrangement became empty. Not to mention the camera highlighted at her which made her nervous. Because it was broadcast live, the pianist couldn't play wrong, there was no repetition. Her 10 years of experience accompanying the congregation in Sunday services gives her the opportunity to be able to play and improvise in any situation.

Of the several shortcomings of the echurch Youtube Livestream worship that have been described, there are also advantages. According to the priest of GKI Taman Cibunut, God's word conveyed through the worship Livestream or e-church is able to go beyond the church walls, even non-Christians can watch the sermons through YouTube account. In this way, the public can recognize the typical church through its preachers; the priest of GKI Taman Cibunut. One obstacle he experienced during the Livestream is that he was not taught online sermon training, digital preaching, and utilizing technology related to preaching or evangelism during his theological school. He further explained that this online ministry becomes very broad and widespread, which can also be felt by people who unexpectedly witness our sermons indirectly. God is omnipresent, He can unite people from various places through online media. So wherever we are, through technology, the congregation can fellowship together. The word of God that the preacher sowed was not only in the pulpit but in other parts of the world.

The impact of religion during the COVID19 pandemic is elevated. In a technologically advanced society, the media have expanded to almost all fields and formed a wide network. The media are taking over the role of the church as a spiritually oriented information provider. Mediation indicates the process by which the core element; face-to-face religious meeting activities, is taken over by the media. As a result, church and congregation interaction is carried out through the media. Content and culture are influenced by the media environment and use the logic of the media. Mediation refers to the communication that takes place between sender and receiver governed by the media. Although this mediation has less impact because the church institution controls the communication, this mediation concerns the special circumstances of the COVID-19 pandemic where the interaction and communication of churches and congregations are regulated through the media. In the long run, the media can change the model of interaction and communication of church institutions and become the most important channel for the spirituality of the congregation. In this case, the church institution, the media as a channel, and the environment lead to changes in content, religious messages to the congregation, including how the congregation worshiped. The e-church mediates the religious activities of Christian spirituality.

The use of computer mediated communication (CMC) is a tool to eliminate the social isolation that was taking place at the time of the COVID-19 pandemic. The presence of visual $\mathrm{CMC}$ can help reduce social isolation and social distancing from friends, family and extended Christian families. E-church worship activities, videocall whatsapp meetings and the use of zoom and googlemeet applications are communication tools both formal and personal.

\section{Conclusions}

Media play an important role in religious institutions. New media are currently being 
used to convey religious messages from the church to its congregants. The media is a channel for the distance between senders and recipients, especially in situations like a prison in the community due to the COVID-19 pandemic with social isolation and social distancing. The digital platform YouTube is an alternative for the church to bridge its religious message. The media provides LiveStream worship for real-time as a substitute for the presence of both parties: the sender (church) and the recipient (congregation). Despite some aspects that congregants usually accept while attending the Sunday Service at the church; such as touch (handshake) expressions, emotions; all are gone. Likewise, worshipers such as song leaders, pianists, psalmists do not get a religious ambiance in the empty church. The priest does not receive feedback in the form of a congregation's response such as nods, smiles that inspire him to deepen the content of the sermon. Even though there are several obstacles in the worship Livestream, such as network technicalities and broadcast stagnation, so far e-church has been able to fulfill the needs of the people to fill their spirituality. The nature of the YouTube Livestream which remains accessible, and the church uploads the worship Livestream on the YouTube channel which can be accessed any time, helps the congregation have the option of watching the Sunday Service online or e-church worship. The e-church worship is almost the same as watching movies; through the cameraman's eyes. Cameraman is the one who determines what kind of movie will be shown. When the camera focuses on the priest, the audience cannot see the left side of the camera which contains the piano player and the song leader.

Worship or Sunday service is the product of the church; which is considered important for the congregant to follow. The church is a producer and the media is a distributor of religious products. The media becomes an environment that provides facilities and communication interactions for church institutions. New media have the ability to penetrate space and time, penetrate the church walls to reach audiences globally. The media can store e-church video data for worship forever through the YouTube platform digital account. For now, almost one-year people worship online and watch e-church and people are getting used to it. No need to be dressed neatly to attend online worship, no need to leave the house, can drink coffee during the worship at home which is not possible in a church, and e-church services can be accessed at any time. It is very possible that the church will continue to provide media access for its congregation in the future. Worship does not need to be done in the church, it does not need to be together with family, done when there is time. And that's the fact. A fellowship that is essentially a gathering of Christian people in the church may slowly fade away. The church is only a building that produces worship shows for its congregation. We are facing an unprecedented reality, a pandemic that was not designed by humans. The creativity of church leaders is needed in reaching people who cannot attend church or it could be that each church institution only produces one service for all, so that the church returns to its original state, not separated. There are a number of limitations to this study; this research was conducted only in Bandung, with a population of 2.3 million, Moslem is the majority. The subjects were Protestant churches with 11 varying numbers of informants. Research on various models of church communication with its congregants is interesting to study, as well as the effect of echurch on the congregation through quantitative design research. Are they satisfied, happy, and know the shortcomings of e-church services, this can be a recommendation for further research.

\section{Acknowledgements}

I extend special thanks and acknowledgement to the London School of Public Relations, Communication and Business Institute-Jakarta for the financial support and the participating Indonesian Christian Church known as Gereja Kristen Indonesia (GKI) Taman Cibunut in Bandung.

\section{References}

Andayani, T. R. (2020). Sumber informasi serta dampak penerapan pembatasan sosial dan fisik pada masa pandemi COVID-19: Studi eksploratif di Indonesia. Jurnal Psikologi Sosial.

Arifianto, Y. A. (2020). Pentingnya Pendidikan Kristen dalam Membangun Kerohanian Keluarga di Masa Pandemi Covid-19. Regula Fidei Jurnal Pendidikan Agama Kristen, 5(2).

Bentzen, J. S. (2020). In Crisis, We Pray: Religiosity and the COVID-19 Pandemic. Covid Economics, (20).

Campbell, H. A. (2012). Understanding the relationship between religion online and 
offline in a networked society. Journal of the American Academy of Religion, 80(1), 64-93.

https://doi.org/10.1093/jaarel/lfr074

Campbell, H. A., \& Delashmutt, M. W. (2014). Studying technology and ecclesiology in online multi-site worship. Journal of Contemporary Religion, 29(2), 267-285. https://doi.org/10.1080/13537903.2014.90 3662

Campbell, H. A., \& Vitullo, A. (2016). Assessing changes in the study of religious communities in digital religion studies. Church, Communication and Culture, l(1).

https://doi.org/10.1080/23753234.2016.11 81301

Chu, C. (2021). Theology of the pain of God in the era of COVID-19: the reflections on sufferings by three Hong Kong churches through online services. Practical Theology, 14(1-2). https://doi.org/10.1080/1756073X.2020.1 864101

Del Valle, S., Hethcote, H., Hyman, J. M., \& Castillo-Chavez, C. (2005). Effects of behavioral changes in a smallpox attack model. Mathematical Biosciences, 195(2). https://doi.org/10.1016/j.mbs.2005.03.006

Djalante, R., Lassa, J., Setiamarga, D., Sudjatma, A., Indrawan, M., Haryanto, B., Warsilah, H. (2020). Review and analysis of current responses to COVID-19 in Indonesia: Period of January to March 2020. Progress in Disaster Science, 6. https://doi.org/10.1016/j.pdisas.2020.1000 91

Gierveld, J. de J., van Tilburg, T., \& Dykstra, P. A. (2009). Loneliness and Social Isolation. The Cambridge Handbook of Personal Relationships, (January), 485-500. https://doi.org/10.1017/cbo978051160663 2.027

GKITC Annual Report. (2020)

Goldstein, P., Weissman-Fogel, I., \& ShamayTsoory, S. G. (2017). The role of touch in regulating inter-partner physiological coupling during empathy for pain. Scientific Reports, 7(1). https://doi.org/10.1038/s41598-01703627-7

Hjarvard, S. (2008). The mediatization of religion: A theory of the media as agents of religious change. Northern Lights: Film and Media Studies Yearbook, 6(1). https://doi.org/10.1386/nl.6.1.9_1

Hooker, J. (2012). Cultural Differences in
Business Communication. In The Handbook of Intercultural Discourse and Communication.

https://doi.org/10.1002/9781118247273.c h19

Hutchings, T. (2011). Community and the Online. Society, (March 2012), 37-41.

Knuth, I., Kouki, M., \& Strube, M. (2013). Is it all about the price? Decision drivers affecting ad placement of media planners in magazines. Journal of Media Business Studies, $\quad 10(3), \quad 65-85$. https://doi.org/10.1080/16522354.2013.11 073568

Molteni, F., Ladini, R., Biolcati, F., Chiesi, A. M., Dotti Sani, G. M., Guglielmi, S., Vezzoni, C. (2021). Searching for comfort in religion: insecurity and religious behaviour during the COVID-19 pandemic in Italy. European Societies, 23(S1). https://doi.org/10.1080/14616696.2020.18 36383

Newport, F. (2020). Religion and the COVID19 Virus in the U.S. Gallup Polling Matters.

Ngwenya, N. B., \& Mills, S. (2014). The use of weblogs within palliative care: A systematic literature review. Health Informatics Journal, 20(1). https://doi.org/10.1177/146045821347589 4

Regus, M. (2021). Regulating religion in a time of COVID-19 pandemic in Indonesia: context, dynamics, and implication. International Journal of Sociology and Social Policy. https://doi.org/10.1108/IJSSP-07-20200321

Sukamto, A., \& Panca Parulian, S. (2021). Religious community responses to the public policy of the Indonesian government related to the covid-19 pandemic. Journal of Law, Religion and State, $\quad 8(2-3), \quad 273-283$. https://doi.org/10.1163/221248102020006

Surna, S., \& Suseno, A. (2020). Pandangan Teologis Live Streaming Atau Zoom Sebagai Sarana Ibadah Bersama Di Masa Pandemi Covid 19. Jurnal Teologi Praktika, 1(2). https://doi.org/10.51465/jtp.v1i2.18

Village, A., \& Francis, L. J. (2020). Faith in Lockdown: Experiences of Rural Church of England Clergy and Laity during the Covid-19 Pandemic. Rural Theology, 18(2). 
https://doi.org/10.1080/14704994.2020.1 818385

Wildman, W. J., Bulbulia, J., Sosis, R., \& Schjoedt, U. (2020). Religion and the COVID-19 pandemic. Religion, Brain and Behavior, Vol. 10. https://doi.org/10.1080/2153599X.2020.1 749339

Yin, R. . (2014). Case study research: Design and methods (2nd editio). Thousand Oaks: Sage.

Yuono, Y. R. (2020). Pertumbuhan Gereja di Masa Pandemi. SAGACITY: Journal of Theology and Christian Education, 1(1). 